\title{
Pengabdian St. Mansyur (1915-1968) Sebagai Guru Surau, Imam Mesjid, dan Imam Tentara dalam Perspektif Pendidikan Islam
}

\author{
Wisber Wiryanto \\ wisberwiryanto@yahoo.com \\ Peneliti Lembaga Administrasi Negara
}

\begin{tabular}{|c|c|}
\hline ARTICLE INFO & \multirow{13}{*}{$\begin{array}{l}\text { ABSTRACT } \\
\text { St. Mansyur (1915-1968) was born in the village of } \\
\text { Guguktinggi, Agam. He is a graduate of the Sumatra Thawalib } \\
\text { Madrasah, Padang Panjang, he is a teacher, mosque imam, } \\
\text { and army priest who has a hierarchical relationship with RE } \\
\text { Martadinata and Bahrum Rangkuti figures who have } \\
\text { research. However, the history has not been studied, so it is } \\
\text { necessary to conduct a study. The research was conducted by } \\
\text { considering the figure of St. Mansyur meets the criteria of } \\
\text { popularity, influence, controversy, uniqueness, integrity, } \\
\text { relevance, and contribution of his thoughts. The results } \\
\text { showed that St. Mansyur as a surau teacher, mosque priest, } \\
\text { and army priest worked with individuals and society with his } \\
\text { diligence and expertise as a form of charity with knowledge } \\
\text { and faith. He contributed ideas about the concept of devotion } \\
\text { as a surau teacher, mosque imam, and army imam which are } \\
\text { forms of the profession in the perspective of Islamic education. } \\
\text { St. Jobs Mansyur as a surau teacher, mosque imam and army } \\
\text { imam are forms of the Islamic education profession that are } \\
\text { taken in stages through a step-by-step process in accordance } \\
\text { with increasing expertise and work experience. Devotion St. } \\
\text { Mansyur as a surau teacher, mosque imam and army imam in } \\
\text { the perspective of Islamic education is a portrait of the } \\
\text { profession of the past; Among the forms of attitude and } \\
\text { behavior that are still relevant to the present need to be used } \\
\text { as a reference. }\end{array}$} \\
\hline$\overline{\text { Artic }}$ & \\
\hline Received, 14 Januari 2022 & \\
\hline Revised, 26 Februari 2022 & \\
\hline 8 Februc & \\
\hline Keywords: & \\
\hline Guguktinggi, Guru, Surau, & \\
\hline Imam & \\
\hline Islam & \\
\hline Interest: & \\
\hline None & \\
\hline Funding: & \\
\hline None & \\
\hline
\end{tabular}

Corresponding Author: Wisber Wiryanto, Pusat Inovasi Administrasi Negara, Lembaga Administrasi Negara, Email: wisberwiryanto@yahoo.com, Phone No.: +6287808784580

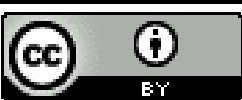

Copyright(C2022, Author(s)

\section{Pendahuluan}

Artikel hasil penelitian ini disusun dengan alasan yang melatarbelakangi, yaitu: (1) adanya tokoh pendidikan Islam di Indonesia tempo dahulu; (2) adanya model pendidikan Islam tempo dahulu yang memiliki unsur, yaitu: surau, imam, guru dan murid; dan (3) adanya bentuk pengabdian dalam pendidikan Islam dengan menjalankan profesi sebagai guru surau, imam mesjid, dan imam tentara yang memiliki kekhasan tersendiri sesuai situasi kondisi masa lalu. Namun, penelitian tokoh dan pengabdian dalam pendidikan Islam di Indonesia masih minim. Upaya 
mengatasinya telah dimulai oleh Abuddin Nata yang melakukan penelitian dan menghasilkan 2 (dua) buah buku, berjudul: (1) Pemikiran Para Tokoh Pendidikan Islam (Nata, 2000); dan (2) Tokoh-tokoh Pembaruan Pendidikan Islam di Indonesia (Nata, 2005).

Sejalan upaya itu, dipandang perlu mengangkat tokoh Sutan (St.) Mansyur yang memiliki pengalaman pekerjaan dalam profesi sebagai guru surau, imam masjid dan imam tentara dan diduga memiliki pengabdian dalam perspektif pendidikan Islam. Meskipun boleh jadi juga diduga ia bukanlah sebagai tokoh dalam ranah ilmu pendidikan Islam masa kini (kontemporer). Namun, peneliti sengaja memberanikan diri menulis artikel mengenai sosok St. Mansyur. Hal ini dilakukan bukan tanpa alasan. Didasarkan pada hasil pengkajian sederhana, ternyata ia berperan dalam berbagai bentuk profesi pendidikan Islam, sebagai guru surau, imam mesjid dan imam tentara.Pengalamannya perlu didesiminasikan agar menjadi bahan pelajaran bagi generasi penerus. Ibarat pepatah "tak kenal maka tak sayang" maka disinilah tempatnya mengangkat nama tokoh alim ulama yang belum dikenal sehingga baik masyarakat umum maupun kalangan akademik pada khususnya bisa mengenali sosok yang telah mengabdikan dirinya masa lalu. Upaya tokoh alim ulama itu sudah sepatutnya dihargai dengan cara mengetahui, memahami, melestarikan, memperkenalkan dan mempraktikkan pengabdiannya bagi kepentinggan pembangunan bangsa, negara dan agama.

Pertimbangan dalam melakukan kajian tokoh St. Mansyur, yaitu: (1) Popularitas: St. Mansyur diasumsikan sebagai tokoh yang popular. Hal ini diindikasikan bahwa ia digelari sebagai guru Mansyur dan buya Mansyur oleh masyarakat di kampungnya. Ia meninggalkan warisan berupa Surau buya Mansyur yang masih berfungsi sampai sekarang. Kecuali itu, seorang saksi hidup purnawariwan kolonel AL yang sudah berusia lanjut, masih segar dalam ingatannya akan sosok Mayor St. Mansyur sebagai imam tentara AL dengan sebutan "pak Imam"; (2) Pengaruh: St. Mansyur sebagai imam tentara merupakan tokoh yang berpengaruh di kalangan AL, sehingga Martadinata sebagai pucuk pimpinan AL selalu menungaskannya berceramah dan menjadi imam shalat tarawih di mesjid yang ada di rumah dinasnya pada bulan Ramadhan karena ia merupakan lulusan sekolah agama Sumatra Thawalib. Pengaruhnya itu, ditunjang pengalaman sebagai guru surau dan imam mesjid; (3) Kontroversial: St. Mansyur merupakan sosok yang menjalani hidup sederhana tak ada upayanya mengumpulkan harta kekayaan dunia, melainkan untuk kebahagiaan dunia dan akhirat. Oleh karena itu, ia tak meninggalkan warisan berupa harta kekayaan dunia melainkan berupa nama baiknya dan contoh yang baik bagi keluarga yaitu anak dan keturunannya, masyarakat, bangsa dan negara; (4) Keunikan: Ia membagi pekerjaan muamalah-nya menjadi dua bagia, yaitu: (a) pekerjaan umum untuk kebutuhan duniawiah-nya dengan bekerja menjalankan usaha dagang dan pengrajin perhiasan emas untuk mencari nafkah dan kebutuhan dunia; dan (b) pekerjaan khusus untuk kebutuhan dunia-akhirat-nya menjalani profesi ranah pendidikan Islam, mulai dari menjadi guru surau, imam mesjid dan imam imam tentara; (5) Integritas di bidang penelitian yang hendak diteliti: Ia memberikan sumbangan pemikiran tentang konsep pengabdian sebagai guru surau, imam masjid dan imam tentara yang merupakan bentuk-bentuk profesi dalam perspektif pendidikan Islam; dan (6) Relevansi dan kontribusi pemikirannya dengan konteks kekinian: Ia ber-muamalah sebagai guru surau, imam mesjid dan imam tentara dengan individu dan masyarakat dengan ketekunan dan keahlian sebagai bentuk amal dengan ilmu dan iman. 
Wisber Wiryanto: Pengabdian St. Mansyur (1915-1968) Sebagai Guru Surau, Imam Mesjid...

Penelitian pengabdian St. Mansyur dalam perspektif pendidikan Islam, dilakukan dengan asumsi St. Mansyur sebagai imam tentara AL (1955-1968) memiliki hubungan hierarki kedinasan dan kedekatan pribadi dengan tokoh RE Martadinata, Menteri/Kepala Staf Angkatan Laut (1959-1966); maupun Bahrum Rangkuti, Kepala Dinas Pemeliharaan Rohani Islam Angkatan Laut (1960-1971). Tokoh tersebut telah diteliti pengabdiannya dan hasilnya dibukukan dengan judul "Siapa Laksamana RE Martadinata" (Ismail dan Sanna, 1977) dan "Bahrum Rangkuti dan Pandangan Dunianya" (Rustapa, 1997). Namun, pengabdian St. Mansyur belum diteliti. Oleh karena itu, dipandang perlu meneliti pengabdiannya dalam perspektif pendidikan Islam.

Berdasarkan latar belakang tersebut, maka dipandang perlu melakukan penelitian pengabdian St. Mansyur sebagai guru surau, imam mesjid dan Imam tentara dalam perspektif pendidikan Islam. Referensi terbaru yang ditemukan masing-masing hanya membahas salah satu dari 3 (tiga) topik, sedangkan penelitian ini membahas ketiganya. Dengan demikian, penelitian ini merupakan sebuah penelitian baru yang berbeda dengan penelitian sebelumnya karena memberi sumbangan pemikiran tentang konsep pengabdian sebagai guru surau, imam masjid dan imam tentara yang merupakan bentuk-bentuk profesi dalam perspektif pendidikan Islam.

\section{Tinjauan Pustaka}

Beberapa hasil penelitian terdahulu mengenai tokoh guru surau, imam mesjid dan imam tentara yang diterbitkan dalam bentuk artikel tahun 2019-2021, sebagaimana disajikan pada tabel 1.

Tabel 1. Penelitian Guru Surau, Imam Mesjid dan Imam Tentara Tahun 2019-2021

\begin{tabular}{|c|c|c|}
\hline No. & Peneliti (Tahun) & Judul Penelitian \\
\hline 1. & $\begin{array}{l}\text { Matanasi, Petrik \& } \\
\text { Ahsan, Ivan Aulia } \\
\text { (2019) }\end{array}$ & $\begin{array}{l}\text { Bey Arifin: Sejarah Hidup Imam Tentara dan Pemikir } \\
\text { untuk Umat }\end{array}$ \\
\hline 2. & Ningsih, Rona (2020) & $\begin{array}{l}\text { Surau Suluk Tertua di Rambah Samo Peninggalan dari } \\
\text { Tuan Guru Syekh Ismail }\end{array}$ \\
\hline 3. & $\begin{array}{l}\text { Abdullah, Wan Mohd } \\
\text { Shaghir (2021) }\end{array}$ & $\begin{array}{l}\text { Syeikh Ahmad Khatib al-Minankabawi - Imam dan } \\
\text { khatib Masjid al-Haram Mekah }\end{array}$ \\
\hline 4. & $\begin{array}{l}\text { Djaelani, M. Anwar \& } \\
\text { Nurfatoni, M. (2021) }\end{array}$ & Yunus Anis Imam Tentara yang pimpin Muhammadiyah \\
\hline 5. & $\begin{array}{l}\text { Imtihani, Nailul } \\
\text { (2021) }\end{array}$ & Sosok KH Sholeh, Imam Masjid Darussalam \\
\hline 6. & $\begin{array}{l}\text { Setiawan, Taufan \& } \\
\text { Baly, Andi (2021) }\end{array}$ & $\begin{array}{l}\text { Anregurutta KH. Abdul Rasyid pernah Imam Masjid } \\
\text { Besar Taqwa Palanro di masanya }\end{array}$ \\
\hline
\end{tabular}

Sumber: Matanasi \& Ahsan (2019), Ningsih (2020), Djaelani \& Nurgatoni (2021), Imtihani (2021), Setiawan \& Baly (2021); data diolah.

Data tersebut menunjukkan, ada 6 (enam) artikel dengan topik dan proporsi, yaitu: (1) artikel penelitian bertopik imam mesjid ada 3 (tiga) artikel (nomor 3, 5, dan 6), proporsinya mencapai separuh (50\%) dari jumlah artikel; dan (2) artikel penelitian tentang imam tentara, sebanyak 2 (dua) artikel (nomor 1 dan 4), proporsinya mencapai sepertiganya (33\%); dan (3) sisanya, artikel penelitian tokoh guru surau, 1 (satu) 
artikel (nomor 2) yang merupakan proporsi terkecil (17\%). Penelitian masing-masing hanya membahas salah satu dari 3 (tiga) topik yaitu: guru surau, imam mesjid dan imam tentara; sedangkan penelitian ini membahas ketiganya. Kecuali itu, tokoh St. Mansyur yang dijadikan sebagai obyek penelitian belum pernah diteliti oleh peneliti lainnya (lihat tabel 1).

Selain itu, ditemukan sebuah hasil penelitian terdahulu yang relevan pembahasannya. Yahdi (2019) menyimpulkan, "Pembinaan Mental Tentara dalam Perspektif Al-Qur'an" adalah segala upaya pembinaan prajurit TNI yang tangguh dengan integrasi 4 (empat) dimensi, yaitu: rohani, ideologi, kejuangan, dan psikologis (beriman/takwa, nasionalis, militan serta sehat psikis). Jadi, relevansinya menggunakan pembahasan dimensi-dimensi pembinaan yang dibahas secara ontologi untuk menjawab pertanyaan mengenai "apa" pembinaan mental? penelitian tersebut membahas masalah secara ontologi. Oleh karena itu, perlu dilakukan penelitian lanjutan yang membahas masalah secara epistemologi dan aksiologi untuk melengkapi hasil penelitian itu. Tafsir dalam bukunya filsafat ilmu mengurai ontologi, epistemologi dan aksiologi pengetahuan itu selengkapnya (Tafsir 2015). Sejalan dengan itu, penelitian ini akan menggunakan pendekatan aksiologi dan epistemologi, yang membedakannya dari penelitian terdahulu yang membahas masalan dengan pendekatan ontologi.

Perbedaan penelitian ini dan yang terdahulu, yaitu: (1) penelitian ini menggunakan dimensi, yaitu: jasmani dan rohani individu, masyarakat dan profesi untuk mencapai tujuan kebaikan hidup dunia dan akhirat dengan bertakwa pada Allah Swt.; dan (2) penelitian ini membahas masalah pengabdian melalui pendekatan aksiologi untuk menjawab pertanyaan, "mengapa" St. Mansyur melakukan pengabdian?; dan pendekatan epistemologi untuk menjawab pertanyaan, "bagaimana" St. Mansyur melakukan pengabdian tersebut? Dengan kata lain, penelitian ini membahas masalah dengan pendekatan aksiologi dan epistemologi; sehingga berbeda dengan penelitian terdahulu yang membahas masalah dengan pendekatan ontologi.

Jadi, penelitian ini merupakan sebuah penelitian baru (novelty) yang berbeda dengan penelitian sebelumnya sehingga manfaat dan kegunaan yang diharapkan, yaitu: (1) melengkapi hasil penelitian terdahulu yang relevan, sehingga tersedia alternatif pembahasan masalah melalui pendekatan ontologi, aksiologi, dan epistemologi untuk pengembangan konsep ilmu pendidikan Islam; (2) memberi sumbangan pemikiran tentang konsep pengabdian sebagai guru surau, imam masjid dan imam tentara yang merupakan bentuk-bentuk profesi dalam perspektif pendidikan Islam; dan (3) berguna sebagai referensi lesson learned oleh generasi penerus.

Kerangka teori yang digunakan meliputi konsep pengabdian dan pendidikan Islam. Pertama, konsep pengabdian dalam perspektif Islam dapat dijelaskan dengan bersumber dari kitab suci al-Qur'an dan Hadits Nabi SAW. Firman Allah Swt. dalam QS. Adzariyat ayat 56, yang artinya, "Dan tidaklah Aku menciptakan jin dan manusia melainkan untuk mengabdi kepadaKu". Hamka (1982) dalam Tafsir Al-Azhar mengkaji ayat tersebut dijelaskan, bahwa mengabdikan diri kepada agama adalah tugas utama dalam hidup dengan cara melakukan dakwah kepada jalan yang baik. Kalau tidak beribadat kepada Allah hidup menjadi tidak berarti. Umur yang terlalu pendek di dunia harus diisi, sehingga walaupun manusia telah mati namun iman dan amal salehnya masih tetap hidup. 
Wisber Wiryanto: Pengabdian St. Mansyur (1915-1968) Sebagai Guru Surau, Imam Mesjid...

Dalam beribadah kepada Allah (mengabdi) dibutuhkan ilmu. Nabi Muhammad Saw bersabda yang artinya, "menuntut ilmu itu wajib atas tiap-tiap muslim". Hadits ini diriwayatkan Ibnu Majah dari Anas, dipandang dla'if oleh al-Baihaqi dan lainnya (AlGhazali, 2013).

Jadi, mengabdikan diri kepada Allah tidak semata-mata dilakukan dengan jalan beribadah, melainkan juga dapat dilakukan dengan jalan bermuamalah yang tujuannya untuk mendapatkan ridha Allah SWT. Oleh karena itu, dalam perspektif pendidikan Islam, kita dapat melihat seseorang yang bermuamalah dengan melakukan pekerjaan, misalnya sebagai guru yang mengajar di lembaga pendidikan, penceramah dan imam di mushola dan masjid dan lain-lain merupakan bentuk-bentuk pengabdian. Pengabdian itu dilakukan untuk mencapai tujuan kesejahteraan masyarakat dan tujuan akhir pendidikan Islam untuk mendapatkan ridha Allah SWT.

Kedua, konsep pendidikan Islam mencakup pengertian, aspek-aspek dan tujuan pendidikan Islam. Menurut Darajat (2009), bila kita akan melihat pengertian pendidikan dari segi bahasa kita harus melihat kepada kata Arab karena ajaran Islam itu diturunkan dalam bahasa tersebut. Pendidikan Islam dalam pengertian bahasa dalam bahasa Arabnya adalah Tarbiyah Islamiyah. Sedangkan pendidikan Islam dalam pengertian istilah, adalah pembentukan kepribadian muslim. Adapun pendidikan Islam dalam pengertian pendidikan dalam Islam, adalah pendidikan iman dan amal saleh yang berisi ajaran tentang sikap dan tingkah laku pribadi masyarakat, menuju kesejahteraan hidup perorangan dan bersama yaitu pendidikan individu dan pendidikan masyarakat.

Konsep tujuan pendidikan Islam bersumber dari firman Allah SWT dalam QS. Ali Imran ayat 102 yang artinya, "Wahai orang-orang yang beriman, bertakwalah kamu kepada Allah dengan sebenar-benarnya takwa; dan janganlah kamu mati kecuali dalam keadaan muslim". Sejalan dengan itu, Tafsir (2010); Kaputra et al., (2021); Engkizar et al., (2021) menjelaskan tujuan pendidikan Islam ialah muslim yang sempurna, atau manusia yang takwa, atau manusia beriman yang beribadah kepada Allah. Sedangkan, Al-Syaibani dalam Nata (2005) menguraikan tujuan pendidikan Islam, menjadi 3 (tiga) tujuan, yaitu: (1) tujuan yang berkaitan dengan individu, mencakup perubahan pengetahuan, tingkah laku, jasmani dan rohani dan kemampuan yang harus dimiliki untuk hidup di dunia dan akhirat; (2) tujuan yang berkaitan dengan masyarakat, mencakup tingkah laku individu dalam masyarakat; dan (3) tujuan profesional yang berkaitan dengan pendidikan dan pengajaran sebagai ilmu, seni, dan profesi.

Berdasarkan uraian tersebut, maka disusun definisi operasional penelitian berupa konsep pengabdian dan pendidikan Islam, yaitu: (1) pengabdian adalah ketekunan menjalankan pekerjaan sehari-hari (muamalah) sebagai sebuah profesi dalam pendidikan Islam dengan tujuan untuk mendapatkan ridha Allah SWT.; dan (2) Pendidikan Islam, mencakup pengertian, aspek-aspek, dan tujuan Pendidikan Islam.

\section{Metode}

Metode penelitian yang digunakan menurut pendekatan dan jenisnya merupakan penelitian kualitatif. Teknik pengumpulan data yang digunakan meliputi studi pustaka yang dilakukan melalui membaca buku, jurnal, majalah, manuskrip dan hasil penelitian dari media cetak, elektronik dan internet untuk mengumpulkan bahan-bahan berupa data sekunder yang relevan. Di samping itu, melalui teknik wawancara dilakukan pencarian data dan informasi dengan mewawancara keluarga tokoh yang diteliti untuk 
mengumpulkan bahan-bahan berupa data primer yang terkait obyek penelitian. Kecuali itu, dilakukan wawancara dengan kolega tokoh yang diteliti. Ada 8 (delapan) orang informan yang memberikan informasi dalam wawancara yang dilakukan. Bahanbahan tersebut dikelompokkan, dibandingkan, dan dianalisis menggunakan pendekatan sejarah dengan memperhatikan kronologi urutan tahun peristiwa yang terjadi. Konfirmasi informan dilakukan setelah hasil penelitian dituangkan ke dalam bentuk naskah.

Teknik analisis data dilakukan melalui: (1) interpretasi, sebagai upaya pemahaman benar terhadap fakta, data dan gejala; (2) induksi dan deduksi. Teknik induksi digunakan untuk menggeneralisasi hasil pengumpulan data yang dirumuskan ke dalam bentuk statement umum. Teknik deduksi digunakan untuk menguraikan kategori-kategori yang relevan dalam pembahasan penelitian ini; dan (3) Analogal (Harahap, 2011) yaitu melakukan analogi dengan kategori yang digunakan tokoh lain untuk maksud yang sama.

Uraian analisis dipilah menjadi 2 (dua) bagian, yaitu: (1) Pembahasan aksiologi untuk menjawab pertanyaan, mengapa St. Mansyur melakukan pengabdian sebagai guru surau, imam mesjid dan imam tentara, dalam perspektif pendidikan Islam? Pembahasan ini dimaksudkan untuk mengetahui alasan, tujuan dan kegunaan pengabdiannya; dan (2) pembahasan epistemologi untuk menjawab pertanyaan, bagaimana pengabdian St. Mansyur tersebut? Pembahasan ini dimaksudkan untuk mengetahui bagaimana cara, proses dan tahapan pengabdiannya. Hasil analisis data digeneralisasi ke dalam bentuk statement umum untuk menarik kesimpulan berupa jawaban pertanyaan mengapa dan bagaimana pengabdian St. Mansyur dalam perspektif pendidikan Islam sehingga benar-benar dapat dibuktikan keberadaannya berdasarkan adanya peninggalan dari tokoh yang bersangkutan.

\section{Hasil}

\section{Masa Kecil, Pendidikan dan Keluarga St. Mansyur}

Masa kecil: St. Mansyur dilahirkan di kampung Guguktinggi, nagari Guguk Tabeksarojo, IV Koto, Agam, Sumatera Barat tahun 1915 (1333 H.). Tahun kelahiran itu bersumber dari tulisan batu nisan makamnya. Sedangkan menurut Armyn (2021) , lahirnya tahun 1912. Ia dilahirkan dari keluarga yang taat beragama, dan sejak kecil terbiasa dengan lingkungan yang memiliki perhatian tinggi dalam kehidupan beragama Islam.

Perihal kedua orang tuanya, yaitu ibunya bernama Rukayah (nama Islam, Ruqayyah suku Sikumbang (1901-1979). Ayahnya, pakih Zaenal Abidin adalah seorang ahli fikih, salah seorang pendiri dan imam mesjid jami' Tabeksarojo, Agam. Pakih atau fakih artinya adalah ahli hukum Islam, ahli fikih (Depdiknas, 2018). Zaenal Abidin. Armyn (2021) menjelaskan, menurut cerita orang-orang tua di kampung, Pakih Zaenal Abidin adalah seorang alim ulama yang mengajarkan ilmu agama bagi masyarakat umat Islam di nagari Guguk Tabeksarojo dan sekitarnya. Dalam memenuhi kehidupan duniawiah dijalankannya usaha berdagang.

St. Mansyur sangat diharapkan oleh orangtuanya agar menjadi orang terpelajar dan memiliki pengetahuan yang luas dalam bidang agama. Sejak kecil ia telah diajarkan ilmu agama, mengerjakan shalat, belajar mengaji al-Qur'an dan Hadits oleh kedua orang tuanya. Di samping itu, ia juga memperoleh pendidikan agama dari pamannya (adik 
Wisber Wiryanto: Pengabdian St. Mansyur (1915-1968) Sebagai Guru Surau, Imam Mesjid...

ibunya) yang bernama H. Muhammad Zen (Majen) adalah seorang ahli agama yang baru kembali dari Mekah pada waktu itu.

Pendidikan: St. Mansyur disekolahkan oleh orangtuanya pada sekolah rakyat yang jadwalnya pagi hari; dan sekolah agama yang jadwalnya siang hari di Guguktinggi, Agam tahun 1920-1924. Atas kerajinan dan ketekunannya maka ia berhasil menamatkan kedua sekolah tersebut dengan baik. Selanjutnya, ia disekolahkan oleh orangtuanya ke jenjang pendidikan agama yang lebih tinggi ke madrasah Sumatera Thawalib Padang Panjang. Thawalib adalah sekolah Islam modern pertama pimpinan Dr. Haka (ayah dari Prof. Dr. Hamka) yang mengelola Thawalib (periode 1911-1926). Ia menempuh pendidikan Thawalib (periode 1925-1931) dengan sistem pendidikan meliputi aspek-aspek guru, murid, metode, kurikulum dan buku pelajaran sebagaimana diuraikan berikut ini.

Gurunya antara lain: (1) Dr. Haka (periode 1911-1926) ayah dari Dr. Hamka; (2) Angku Mudo Abdul Hamid Hakim (periode 1911-1946), keduanya sebagai pimpinan Thawalib yang juga mengajar murid tingkat terakhir; dibantu oleh guru-guru yang mengajar murid tingkat permulaan (Afifi, 2021) terrmasuk guru-guru lainnya. Oleh karena itu, tak heran jika ia memiliki pengetahuan dan keahlian dalam ilmu agama dan menduduki posisi yang tinggi dalam ranah pendidikan Islam dengan mengabdi sebagai guru surau, imam mesjid dan imam tentara di kemudian hari. Murid-murid semasa sekolah Thawalib, yaitu sahabatnya yang memiliki periode pendidikan beririsan dengannya, kemudian menjadi alumni Thawalib, terjun ke masyarakat dan menduduki jabatan penting sehingga menjadi tokoh pendidikan Islam, sebagaimana disajikan di tabel 2.

Perolehan data menunjukkan, murid-murid semasa St. Mansyur di Thawalib, antara lain 2 (dua) orang kakak kelas; dan 3 (tiga) orang adik kelasnya. Profesi mereka setelah tamat Thawalib, sebagian besar sebagai penulis buku, sebagian lainnya sebagai guru besar, selain itu ada yang sebagai gubernur kepala daerah, termasuk imam tentara (lihat tabel 2).

Tabel 2. Alumni Madrasah Thawalib yang Periode Pendidikannya Beririsan dengan St. Mansyur

\begin{tabular}{crrl}
\hline No. & \multicolumn{1}{c}{ Alumni } & Periode & \multicolumn{1}{c}{ Profesi } \\
\hline 1. & H. Sulaiman Rasyid & $1919-1926$ & $\begin{array}{l}\text { Guru Besar Ilmu Fiqh dan penulis } \\
\text { buku Fiqh }\end{array}$ \\
2. $\begin{array}{l}\text { Prof. K.H. Zainal Abidin } \\
\text { Ahmad }\end{array}$ & $1923-1926$ & $\begin{array}{l}\text { Rektor Perguruan Tinggi Ilmu Al- } \\
\text { Qur'an dan penulis buku pelajaran } \\
\text { pendidikan Islam }\end{array}$ \\
3. St.Mansyur Mayor Tituler $1925-1931$ & $\begin{array}{l}\text { Guru Surau, Imam Mesjid dan Imam } \\
\text { Tentara }\end{array}$ \\
4. H. Oemar Bakry & $1927-1932$ & $\begin{array}{l}\text { Penulis Tafsir Rahmat dan buku } \\
\text { pelajaran }\end{array}$ \\
5. K.H. Imam Zarkasyi & $1930-1932$ & $\begin{array}{l}\text { Pendiri Pondok Pesantren Gontor } \\
\text { dam penulis buku Fiqh, Ushuluddin, } \\
\text { dan Tajwid }\end{array}$
\end{tabular}


6. Prof. H. Ali Hasjimi
1931-1935 Gubernur Provinsi DI Aceh, Rektor

IAIN Ar-Raniry, penulis buku

pendidikan Islam

Sumber: Armyn (2021), Bakry (1984), Darajat (2008), Helmy (2020), Rasyid (1992), Zulkarnain (2017); data diolah.

Salah seorang di antaranya, H. Sulaiman Rasyid (periode 1919-1926) melanjutkan pendidikan keluar negeri untuk mendalami ilmu pengetahuan pada pendidikan guru di sekolah Muallim, Mesir, 1926; dan pendidikan Takshashshus Fiqh (spesialis ilmu hukum) di Universitas al-Azhar, Kairo, Mesir, 1927-1935. Dalam hal ini, St. Mansyur sebagai salah satu lulusan terbaik Thawalib mendapat beasiswa untuk melanjutkan pendidikan ke Mekah, tapi tidak lulus persyaratan karena anak tunggal.

Afifi (2021) menjelaskan, Dr. Haka dalam proses belajar mengajar mengunakan buku pelajaran berupa kitab-kitab yang berasal dari Mesir, antara lain: kitab tafsir alManar oleh M. Abduh untuk pelajaran ilmu Tafsir; dan kitab Risalah Tauhid oleh M. Abduh untuk pelajaran ilmu Tauhid. Kurikulum dan buku pelajaran yang diajarkan oleh guru di Thawalib, meningkatkan keahlian St. Mansyur dalam membaca, menulis, dan percakapan bahasa Arab serta hafalan al-Qur'an -nya sejak kecil sehingga menjadi hafidz al-Qur'an, mampu berpidato dan berdakwah. Untuk menambah wawasan ilmu agama, St. Mansyur juga belajar kepada tokoh alim ulama yang ada di daerahnya, sebut saja Syekh Ibrahim Musa yang bergelar Inyiak Parabek (1884-1963).

Kedua orangtuanya sangat mengharapkan anaknya menjadi orang terpelajar dan memiliki pengetahuan yang luas dalam Imu agama. Sejalan dengan itu, St. Mansyur bercita-cita menjadi guru dan mengajar di kampungnya. Murid-murid lainnya, sudah barang tentu juga bercita-cita menjadi guru agama dan mengajar di kampung masingmasing nantinya berbekal ilmu agama yang diperoleh dari Thawalib. Untuk mewujudkan cita-citanya, maka St. Mansyur mendirikan sebuah surau yang berdekatan dengan rumahnya berupa bangunan kayu di atas tanah yang luasnya kurang lebih 100 (seratus) meter persegi di kampung Guguktinggi. Surau itu dibangun sebelum tamat Thawalib tahun 1931. Surau itu semula digunakan sebagai tempat praktek pelajaran yang diperoleh dari Thawalib, yaitu praktek mengajar sebagai guru, mengaji dan mempelajari al-Qur'an dan Hadits, serta menyimpan buku-buku pelajaran. Jadi, dengan begitu, ia berhasil tamat pendidikan sebagai lulusan terbaik Thawalib yang merupakan sekolah Islam modern pertama. Thawalib adakalanya mengusahakan beasiswa bagi lulusan terbaiknya untuk melanjutkan pendidikan ke jenjang yang lebih tinggi keluar negeri antara lain ke Mesir atau ke Mekah sehingga berpeluang sekaligus menunaikan ibadah haji ke tanah suci dalam masa pendidikannya.

Melalui wawancara dengan informan diperoleh informasi, bahwa St. Mansyur pernah mendapatkan beasiswa pendidikan ke Mekah, tapi tidak lulus persyaratan karena sebagai anak tunggal. Setelah tamat Thawalib ia meningkatkan penggunaan surau sebagai tempat mengajar mengaji al-Qur'an dan Hadits. Sebagai guru surau ia menerima murid untuk belajar mengaji al-Qur'an dan Hadits di kampung Guguktinggi.

St. Mansyur memperoleh ujian hidup karena ayah yang mengasuh, membimbing dan mengajari dalam ilmu agama sehingga terbiasa dengan lingkungan yang memiliki perhatian tinggi dalam kehidupan beragama Islam, meninggal dunia. Ia sangat diharapkan oleh orangtuanya agar menjadi orang terpelajar, memiliki pengetahuan yang luas dalam bidang agama, dan meneruskan pekerjaan yang telah dijalani semasa hidup ayahnya. 
Wisber Wiryanto: Pengabdian St. Mansyur (1915-1968) Sebagai Guru Surau, Imam Mesjid...

Pernikahan St. Mansyur dan Latifah terjadi di kampung Guguktinggi pada tahun 1931. Dalam acara walimah pernikahan, St. Mansyur mendapat gelar adat "Sutan" yang ditulis dengan singkatan St. Sutan merupakan kata sapaan atau gelar adat Minangkabau (Depdiknas, 2018). Sutan ialah gelar adat Minangkabau yang diberikan kepada seseorang yang telah menikah. Seorang yang telah menikah tidak dipanggil namanya lagi melainkan dipanggil dengan gelar "Sutan" terutama oleh keluarga pihak istri yang bersangkutan.

Melalui wawancara diperoleh informasi dari informan, bahwa $\mathrm{Hj}$. Latifah menunaikan ibadah haji ke tanah suci Mekah dengan kapal laut pertengahan tahun 1970-an. Ia kembali ke tanah air membawa oleh-oleh, air zam-zam untuk anak dan cucunya dengan harapan memberi keberkahan dan doa semoga bisa menunaikan ibadah haji ke tanah suci Mekah pula di kemudian hari. Sedangkan St. Mansyur pernah ditawari sumbangan ongkos naik haji pada waktu bertugas sebagai imam tentara. Namun, ia tidak mau menerima sumbangan itu karena kewajiban haji salah satunya ialah sanggup. Al-Ghazali (2013) menjelaskan, syarat-syarat yang mewajibkan haji, ialah lima: baligh, Islam, berakal, merdeka dan sanggup. Sanggup dalam perongkosan dan belanja keluarga untuk orang yang ditanggungnya.

Penulis memperoleh informasi dari informan dalam wawancara, bahwa St. Mansyur memiliki pekerjaan sehari-hari baik kategori pekerjaan umum maupun khusus dalam profesi pendidikan Islam. Pekerjaan yang umum, yaitu menjalankan usaha dagang. Ia memiliki famili yang menekuni usaha dagang emas dan kain. Adakalanya, ia dan Syamsuddin familinya menjalankan usaha dagang ke Singapura yang dikenal sebagai pusat perdagangan pada tahun 1947. Kemudian, ia menjalankan usaha dagang di kota Bukittinggi. Ia dan keluarganya tinggal di jalan Kampung Baru, Bukittinggi pada tahun 1949-1953. Sedangkan Syamsuddin pergi merantau ke kota Medan menjalankan usaha dagang dan bersama keluarganya tinggal di jalan Utama, Medan pada tahun 1951. Kemudian, St. Mansyur menyusul pergi merantau pula ke kota Medan untuk menjalankan usaha dagang sambil mencari peluang usaha dan suasana baru di kota itu. Ia dan keluarganya tinggal bersama keluarga Syamsuddin tersebut sementara waktu, kemudian pindah rumah ke jalan Puri, Medan pada tahun 19531954.

Berdasarkan wawancara penulis dengan informan maka diperoleh informasi mengenai pekerjaan baik St. Mansyur maupun istrinya untuk memenuhi kebutuhan keluarga. Di samping usaha dagangnya, ia juga melakukan aktivitas lain sebagai pengrajin emas yang membuat perhiasan cincin, anting-anting dan lain-lain. Pekerjaan itu merupakan keterampilan turun-temurun masyarakat kampung Guguktinggi. Ia bekerja dengan tanggungjawab, pelanggan digaransi perbaikan apabila terjadi kerusakan. Sementara, istrinya di samping mengurus rumah tangga, juga bekerja di usaha konveksi; dan menjahit pakaian anak yang hasilnya dijual ke pasar. Dari keterangan itu, diketahui bahwa mereka bekerja bahu membahu untuk memenuhi kebutuhan keluarga.

St. Mansyur diangkat dalam jabatan sebagai imam tentara AL dan mendapat tugas penempatan pertama di Surabaya tahun 1955. Ia membagi pekerjaan muamalah-nya menjadi 2 (dua) bagian: (1) pekerjaan umum untuk kebutuhan duniawiah-nya dengan bekerja menjalankan usaha dagang untuk mencari nafkah dan kebutuhan dunia; dan (2) pekerjaan khusus untuk kebutuhan dunia akhiratnya menjalani profesi ranah pendidikan Islam, yaitu: (a) Guru surau, profesi ini dilakukan dengan mengajar di 
suraunya sendiri, sebagai praktek mengamalkan ilmu menjelang dan setelah tamat Thawalib, pada tahun 1931-1953. (b) Imam mesjid, sebagai imam mesjid Tabeksarojo, profesi ini dijalani pada tahun 1932-1953; dan (c) imam tentara, profesi ini dijalani pada tahun 1955-1968.

St. Mansyur sebagai Guru Surau: St. Mansyur bersekolah di Thawalib bercita-cita menjadi guru dan mempunyai tempat mengajar murid-murid di kampungnya. Maka, ia membangun surau di dekat rumahnya dengan uang yang dikumpulkan dari upah bekerja menjalankan usaha dagang. Surau tersebut dibangun menjelang ia tamat sekolah Thawalib; dan digunakan untuk tempat praktek mengajar mengaji dan mempelajari al-Qur'an dan Hadits, serta menyimpan buku-buku pelajaran Thawalib pada awalnya. Dengan dibangunnya surau sebelum tamat pendidikan Thawalib menunjukkan bahwa ia mempunyai perhatian untuk memajukan masyarakat dalam pendidikan Islam. Dengan kata lain, ia mempunyai pemikiran maju tentang perlunya praktek pendidikan Islam, dimana praktek mengajar dapat dilakukan di sebuah tempat yaitu surau sederhana. Surau tersebut ternyata menjadi sebuah peninggalan yang penting di kemudian hari.

Surau itu meningkat penggunaannya, tidak hanya sekedar tempat "praktek" mengajar sebagai guru melainkan mengajar dengan berprofesi sebagai guru, menerima murid untuk mengaji dan mempelajari al-Qur'an dan Hadits setelah tamat Thawalib. Ia juga menggunakan surau untuk menyiapkan bahan-bahan ceramah agama, menulis buku pelajaran agama, berdiskusi dan berdakwah. Ia mengajar dengan cara tradisional, yaitu dengan sistem Halaqah. Nata (2000) menjelaskan, sistem Halaqah adalah cara pengajaran yang dilakukan dengan cara seorang guru didatangi oleh murid-muridnya. Mereka duduk melingkar di sekeliling guru sambil mengikuti pelajaran yang disampaikan oleh guru.

Ia mengajar sebagai guru surau untuk mempraktekkan dan mengamalkan ilmu agamanya menjelang dan setelah tamat Thawalib pada periode tahun 1931-1953. Oleh karena itu, ia dikenal dan disapa oleh masyarakat Guguktinggi dengan gelar "guru Mansyur" untuk menghormatinya. Menyapa nama seseorang dengan gelar "guru" di depan namanya, adalah kebiasaan lokal yang bisa dijumpai di ranah Minangkabau. Arti kata "guru" adalah orang yang pekerjaan, mata pencaharian atau profesinya mengajar (Depdiknas, 2018). Di samping itu, terdapat alim ulama yang juga mengajar ilmu agama digelari "guru" oleh masyarakat di kampung Guguktinggi. Mereka, antara lain guru Sjarbaini, guru H. Sofyan, guru H. Musa dan guru H. M. Dalil. Sedangkan diantara mereka, yang masih ada ialah guru yang disebut terakhir, ia berusia panjang sehingga genap 100 (seratus) tahun umurnya pada tahun 2021 ini. Jadi, sapaan guru di depan nama alim ulama (ahli agama) itu berkaitan dengan profesi mereka sebagai guru yang mengajar agama.

Namun, kegiatan mengajar di surau itu terhenti karena ia menjalankan tugas (di berbagai daerah lain) sebagai imam tentara AL (1955-1968). Surau tersebut terbengkalai dan tidak berfungsi sebagaimana seharusnya. Selanjutnya, atas inisiatif masyarakat kampung Guguktinggi dan khususnya suku Sikumbang dan karib kerabat terdekat maka diupayakan untuk mengaktifkan kembali fungsi surau tersebut. Dengan melakukan pengumpulan dana digunakan untuk biaya pembangunannya sehingga "surau Guru Mansyur" berdiri dan berfungsi kembali sebagai lembaga Pendidikan Addinul Islam (Armyn, 2021). Sama halnya, Rahmansyah (2020) menjelaskan, "surau buya Mansyur" sebagai salah satu sarana prasarana pelaksanaan kegiataan keagamaan 
Wisber Wiryanto: Pengabdian St. Mansyur (1915-1968) Sebagai Guru Surau, Imam Mesjid...

yang kondisinya layak pakai dan digunakan di kampung Guguktinggi, Agam sampai sekarang. Arti kata "buya" ialah kata sapaan islami kepada orang tua laki-laki. Arti lainnya, gelar ulama di ranah Minang (Depdiknas, 2018). Jadi, surau itu dinamakan orang "surau guru Mansyur" atau "surau buya Mansyur", karena ia disapa "guru Mansyur" atau "buya Mansyur" oleh masyarakat di kampung Guguktinggi semasa hidupnya (lihat gambar 1).

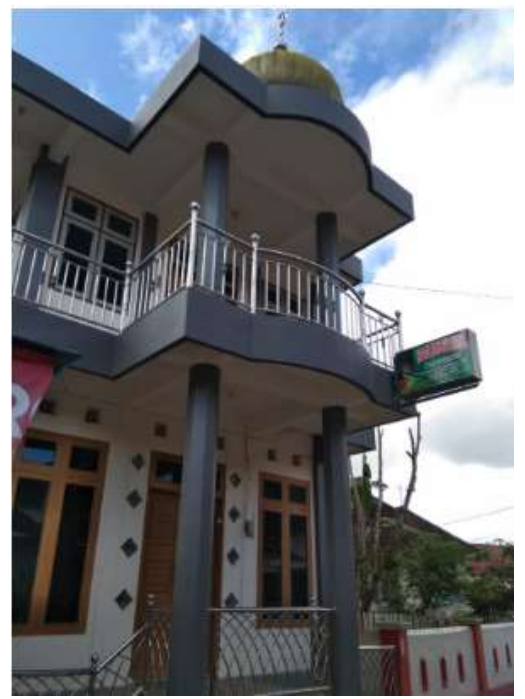

Gambar 1: Foto surau buya Mansyur di kampung Guguktinggi, Agam pada tahun 2021

Sumber: Dokumentasi Armyn (2021)

St. Mansyur sebagai Imam Mesjid: St. Mansyur dipilih sebagai imam mesjid melanjutkan pekerjaan ayahnya yang telah meninggal dunia. Pekerjaan imam mesjid merupakan pekerjaan tambahannya di samping sebagai guru surau. Ia membagi waktu dengan cara menyusun jadwal menangani kedua pekerjaan tersebut. Guru surau dan imam mesjid merupakan bentuk profesi yang sama-sama berada dalam ranah pendidikan Islam. Baik surau maupun mesjid tempat ia mengabdi serta rumahnya saling berdekatan lokasinya di kampung Guguktinggi sehingga ia bisa pulang pergi dengan mudah untuk mengerjakan urusan pekerjaannya. Dengan kata lain, kondisi tersebut mempermudah upayanya melaksanakan pekerjaan sehari-hari (mualamah) dengan profesi ganda baik sebagai guru surau maupun imam mesjid di kampungnya.

Mesjid jami' Tabeksarojo sesuai namanya sebagai mesjid jami' menyelenggarakan shalat Jumat di mesjid ini. St. Mansyur sebagai imam mesjid jami' mengelola urusanurusan penyelenggaraan kegiatan shalat Jum'at dan kegiatan keagamaan lainnya.

Berdasarkan wawancara penulis dengan informan, maka diperoleh informasi mengenai sikap St. Mansyur sebagai penceramah (khatib) mesjid, bahwa ia menyiapkan catatan naskah yang bersumber dari kitab-kitab yang dimilikinya manakala akan berkhotbah. Ceramahnya didahului dengan bersikap tenang, wajah yang jernih memberi senyuman dan salam kepada para jemaah mesjid. Ia memulai ceramahnya dengan memanjatkan puji syukur kehadirat Allah Swt. serta shalawat dan salam kepada nabi Muhammad SAW. Kemudian, ia menyampaikan isi ceramahnya secara berurutan dengan berdasarkan kepada al-Qur'an dan Hadits, sambil memberikan pesan-pesan. Adakalanya, ia menyampaikan isi ceramah dan khotbah mengenai jihad fisabilillah, sesuai dengan zaman yang dialamiya. Akhirnya, ia menutup ceramahnya dengan doa. 
Melaui wawancara dengan informan diperoleh informasi mengenai St. Mansyur sebagai Walinagari kampung Guguktinggi, ia memiliki banyak pengalaman. Sebuah pengalaman menegangkan yang terjadi di akhir masa penjajahan, manakala ada seorang tentara Belanda yang berkunjung untuk bertemu di rumahnya. Kemudian, ia menerimanya di ruang tamu, mempersilakan duduk dan bercakap-cakap dalam bahasa Belanda. Dari percakapan itu, maka diketahui maksud kedatangannya mengadakan inspeksi untuk mengetahui keadaan situasi kondisi kampung itu yang berbatasan dengan kota Bukittinggi. St. Mansyur tak lupa menyuguhi tamunya hidangan sesisir pisang dan minuman untuk menghormati tamunya. Setelah pembicaraan selesai dan tentara Belanda itu pulang. Ada diantara masyarakat kampung Guguktinggi yang tidak senang dengan sikap St. Mansyur tersebut yang dianggapnya lunak terhadap penjajah. Sambil mengatakan, Mengapa Belanda itu diberi pisang tidak diberi pisau? St. Mansyur menjelaskan kepadanya, kalau diberi pisau maka kampung ini akan dihabisi oleh tentara Belanda.

St. Manyur sebagai Imam Tentara hingga akhir hayatnya: Pada masa Laksamana Madya R. Soebijakto menjabat KSAL diterbitkan Surat Keputusan KSAL No. G 11/5/11 tanggal 21 Juli 1953 sebagai dasar pembentukan Dinas Pemeliharaan Rohani AL yang meliputi Islam, Protestan dan Katolik (Disbintal.com, 2021). Dinas tersebut memiliki tugas dan fungsi untuk memelihara rohani di lingkungan AL. Dalam rangka pelaksanaan tugas dan fungsinya maka diadakan jabatan Imam Tentara. St. Mansyur, Mayor Tituler adalah salah seorang imam tentara dari dinas tersebut periode 19551968

St. Mansyur sebagai Imam Tentara di Surabaya: Sebelum bekerja sebagai Imam Tentara, St. Mansyur bekerja menjalankan usaha dagang di Medan. Pada saat itu, ia berjumpa dengan salah seorang sahabat lamanya di Thawalib yang telah bekerja sebagai tentara AL. Sahabatnya menawari untuk bekerja karena pada saat itu sedang dibuka lowongan kerja untuk jabatan tersebut, dan ia memenuhi persyaratan untuk menduduki jabatan itu sesuai dengan pendidikan dan pengalamannya. Setelah ia membulatkan niatnya untuk melamar pekerjaan itu dengan menitipkan surat lamaran kepada sahabatnya, kemudian Ia diangkat dalam jabatan Imam Tentara .

St. Mansyur mengawali tugasnya sebagai imam tentara AL di Surabaya pada periode tahun 1955-1962. Ia dilantik dalam jabatan imam tentara dengan diberikan pangkat Kapten Tituler, kemudian naik pangkat menjadi Mayor Tituler dalam periode itu. Jika diperhatikan, nomor NRP-nya masih bisa dihitung jari, maka ia merupakan salah seorang prajurit senior sehingga ada hubungan kerja hirarki dengan KSAL Martadinata pada waktu itu. Hubungan keduanya dapat diteliti dari perspektif pendidikan Islam. 
Wisber Wiryanto: Pengabdian St. Mansyur (1915-1968) Sebagai Guru Surau, Imam Mesjid...

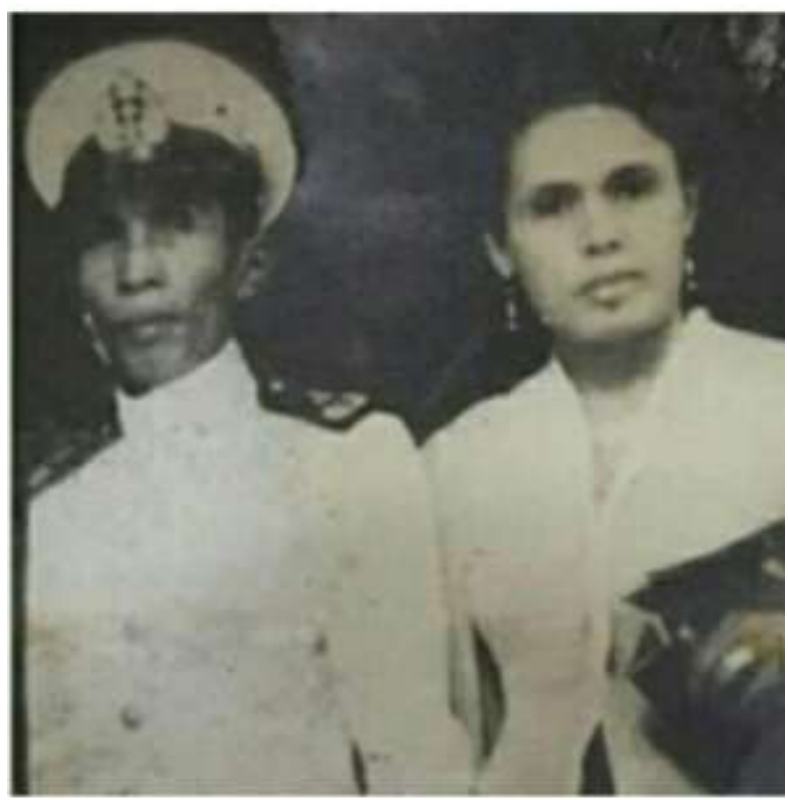

Gambar 2: Foto St. Mansyur dan istri, tahun1956.

Sumber: Dokumentasi Rasdianto (2021)

Martadinata pernah mengatakan bahwa melaksanakan ibadah puasa, sesungguhnya adalah mengandung makna yang penting dalam menuju kepada nation and character building bangsa Indonesia. Dalam menghadapi berbagai masalah perjuangan, character building harus merupakan pokok atau dasar analisa yang terutama. Dalam sejarah ummat yang sangat menentukan, oleh karena kebesaran sesuatu bangsa selalu dinilai daripada kebesaran character bangsa itu. Karena itu membina character atau watak yang baik perlu diteruskan dan dilakukan dalam membina nation Indonesia. Kalau telah selesai melaksanakan ibadah puasa dapat dirasakan bahwa jasmaniah dan rohaniah betul-betul terlatih, untuk melaksanakan tugas-tugas selanjutnya" (Ismail dan Burhanuddin, 1977).

Martadinata selalu menugaskan St. Mansyur untuk menjadi imam shalat berjemaah selama bulan puasa Ramadhan dan mengadakan pengajian yang waktunya diantara shalat Isya dan shalat Tarawih dan Witir di mesjid di rumah dinasnya, Jl. Diponegoro, Jakarta Pusat. Apa yang ditugaskan itu sejalan dengan keahlian St. Mansyur sebagai tamatan sekolah agama yaitu madrasah Thawalib. Sebagai imam shalat Jum'at, ayat suci Al-Qur'an dilafalkan dengan jelas dan fasih. Begitu juga pengalamannya sebagai guru surau, dan imam mesjid yang membentuk keahliannya sebagai imam shalat dan berdakwah.

Pimpinan AL tersebut punya perhatian terhadap suasana kehidupan keagamaan di lingkup organisasi, dengan merayakan peringatan hari besar seperti hari raya Iedul Fitri dan Iedul Adha termasuk peringatan Isra Miraj dengan berbagai kegiatan. Mengenai hal ini, diperoleh informasi dari sumber berita TNI-AL bulan Pebruari 1960, bahwa "Satu setengah bulan lagi rakyat Indonesia merayakan Idul Fitri, semua orang sedapat mungkin berpakaian serba baru, dan untuk jamuan dibutuhkan bahan makanan yang tidak sedikit. Namun, pelayaran niaga dalam keadaan morat-marit, karena kongesti (penuh sesak) di semua pelabuhan; mis-management; adanya "pencoleng" berkeliaran di pelabuhan; dan penyelundupan. Dengan faktor yang buruk ini, lebaran harus dirayakan oleh semua umat Islam sebanyak kira-kira 50 juta yang tersebar di 13.000 pulau" (TNI-AL, 1970). 
Berita itu menunjukan adanya perhatian di lingkungan AL akan permasalahan yang dihadapi umat Islam yaitu masalah ketersediaan sandang dan pangan di hari lebaran. Permasalahan itu tentu menjadi perhatian unit kerja AL terkait untuk mengatasinya Permasalahan itu terkait tugas dan fungsi Dinas Pemeliharaan Rohani Islam AL termasuk Imam Tentara AL untuk mencari langkah-langkah pemecahannya. Namun, jabatan Kepala Dinas itu belum terisi. Oleh karena itu, dirasakan adanya kebutuhan mendesak (urgen) untuk mengisi jabatan yang lowong itu dengan segera. Maka St. Mansyur mengusulkan kepada Martadinata, nama Bahrum Rangkuti untuk mengisi jabatan itu.

St. Mansyur telah mengenal Rangkuti sebagai penulis buku dan artikel. Selain itu juga Intisari (1964) dan Rustapa (1997) menguraikan latar belakang Rangkuti menjadi Kepala Dinas tersebut, bahwa ia pernah berceramah tentang aspek sosial hari raya Mikraj dan masalah perawatan rohani di hadapan perwira dan KSAL Martadinata (1959-1966) di balai prajurit Diponegoro, pada waktu itu dengan begitu memikat. Sehingga ia pun diminta untuk jabatan itu. Kemudian, dilantik dalam jabatan itu dengan pangkat kolonel tituler. Sayangnya, uraian itu tidak lengkap sebab tidak menjelaskan sosok St. Mansyur sebagai imam tentara AL yang telah mengantarkan Rangkuti ke jabatan itu. untuk melengkapi uraian tersebut diperoleh informasi dari informan dalam wawancara, bahwa St. Mansyur pernah diminta oleh Martadinata untuk mencarikan orang yang tepat sebagai calon Kepala Dinas Pemeliharaan Rohani Islam AL. Kemudian, ia mengusulkan Rangkuti sebagai calon itu, dengan pertimbangan pendidikannya sarjana dan sebagai penulis buku dan artikel yang terkait dengan tugas jabatan itu. Setelah usulannya disetujui, maka.ia menghubungi yang bersangkutan. Selama mengurus persyaratan lamaran pekerjaan dalam jabatan itu, Rangkuti tinggal di rumah dinas keluarga St. Mansyur di jalan Opak No.43, Surabaya.

Diperoleh informasi dari informan dalam wawancara mengenai pengabdian Mayor St. Mansyur, bahwa selain bertugas sebagai imam tentara AL di Surabaya, ia pernah ditugaskan ikut melaksanakan tugas operasi untuk mengatasi pemberontakan Permesta di Menado. Mengenai hal ini diperoleh catatan, bahwa tentara AL telah melaksanakan tugas antara lain operasi merdeka untuk penghancuran Permesta di Menado tahun 1958 (ALRI, 1960). Sebagai Imam Tentara AL di Surabaya (1955-1962), ia selama menjalankan tugas diberi fasilitas kendaraan sebuah mobil jeep dan sebuah rumah dinas di jalan Opak No. 43, Surabaya. Selesai bertugas disana kemudian ia dipindahtugaskan sebagai imam tentara AL di Medan (1962-1964). Ia tidak lupa mengembalikan semua fasilitas itu kepada negara.

St. Mansyur sebagai Imam Tentara di Medan: Setelah bertugas di Surabaya maka ia ditempatkan sebagai imam tentara di Medan tahun 1962-1964. Armyn (2021) menjelaskan, St. Mansyur selaku imam tentara bertugas menjalankan disiplin bagi para tamtama, bintara dan perwira dalam menegakkan syariat islam di instransinya. Apabila ia menemukan penyimpangan yang dilakukan oleh tentara AL dalam bidang agama maka ia akan memanggil yang bersangkutan untuk diberikan nasehat. Begitu juga, apabila ia mendapat informasi tentang adanya tentara yang membawa wanita yang bukan muhrim-nya ke rumah dinas AL, maka tentara yang bersangkutan akan dipanggil ke kantor atau ke rumah untuk diberikan nasehat yang sesuai dengan ketentuan ajaran agama.

Dinas Pemeliharaan Rohani Islam AL juga mempunyai kegiatan menyelenggarakan perayaan, jika ada hari besar umat Islam, misalnya peringatan 
Wisber Wiryanto: Pengabdian St. Mansyur (1915-1968) Sebagai Guru Surau, Imam Mesjid...

Maulid Nabi Muhammad SAW. Mayor St. Mansyur sebagai imam tentara berperan sebagai penceramahnya. Perayaan itu diisi dengan kegiatan membaca kitab suci alQur'an dan ceramah dengan mengundang khalayak ramai umat Islam serta menyediakan makanan dan minuman.

Sikap Mayor St.Mansyur ketika ia melaksanakan kegiatan pencetakan kitab suci AlQur'an terdapat sisa anggaran pengadaan tersebut maka dikembalikan ke negara. Di samping itu, dalam bertugas sebagai imam tentara $\mathrm{AL}$, ia juga telah mengislamkan sebanyak 7 (tujuh) orang; dan 3 (tiga) orang diantaranya bertugas sebagai dokter AL. St. Mansyur sebagai imam tentara AL di Medan dalam menjalankan tugas diberi fasilitas kendaraan sebuah mobil jeep dan sebuah rumah dinas di Belawan, Medan. Setelah selesai bertugas di Medan (1962-1964) maka ia tidak lupa mengembalikan fasilitas tersebut kepada negara.

St. Mansyur sebagai Imam Tentara di Tanjungpinang: Setelah bertugas di Medan maka ia ditempatkan sebagai imam tentara di Tanjungpinang tahun 1964-1968. Armyn (2021) menjelaskan mengenai urusan yang dlakukan oleh St. Mansyur sebagai imam tentara, bahwa ia selaku imam tentara bertugas menjalankan disiplin bagi para bintara dan perwira dalam menegakkan syariat Islam di instansinya. Apabila ia menemukan penyimpangan yang dilakukan oleh tentara AL dalam bidang agama maka ia akan memanggil yang bersangkutan untuk diberikan nasehat. Begitu juga, apabila ia mendapat informasi tentang adanya tentara yang membawa wanita yang bukan muhrimnya ke rumah dinas AL, maka tentara yang bersangkutan akan dipanggil ke kantor atau ke rumah untuk diberikan nasehat yang sesuai dengan ketentuan ajaran agama.

Selain itu, St. Mansyur juga menjadi khatib tetap di Masjid Raya Tanjungpinang, dan mengadakan pengajaran pendidikan Islam bagi keluarga Muslim yang ada di Tanjungpinang (Armyn, 2021). Kegiatan ini mempunyai relevansi dengan pengalamannya sebagai imam di mesjid jami' Tabeksarojo di kampung Guguktinggi, sebagaimana telah disebutkan.

Dinas Pemeliharaan Rohani Islam AL tampaknya selalu giat menyelenggarakan perayaan hari besar umat Islam baik di Jakarta, Medan dan Tanjungpinang. Jika ada hari besar umat Islam, misalnya peringatan Maulid Nabi Muhammad SAW Mayor St. Mansyur juga berperan sebagai penceramah dalam perayaan Maulid tersebut. Perayaan itu diisi dengan kegiatan membaca kitab suci al-Qur'an dan ceramah dengan mengundang khalayak ramai umat Islam serta menyediakan makanan dan minuman. Kecuali itu, ia sebagai imam tentara tidak mau menerima sumbangan. Jika terdapat sisa anggaran kegiatan tersebut maka dikembalikan ke negara. Dalam hal ini, ia pernah mendapati peti-peti botol minuman di bagasi mobilnya, ternyata diberikan sebagai sumbangan toko tempat membeli konsumsi kegiatan itu, tapi semuanya dikembalikan karena ia tidak mau menerima sumbangan.

Kesibukan Mayor St. Mansyur di samping bertugas sebagai imam tentara, juga melaksanakan tugas lainnya yaitu sebuah pekerjaan besar seperti memimpin pembangunan Taman Makam Pahlawan (TMP) di Tanjungpinang. Pekerjaan itu selesai dan penggunaannya diresmikan di awal tahun 1968. Hal ini menunjukkan, bahwa sikapnya bertanggungjawab dan amanah dalam melaksanakan tugas. Pekerjaan itu sama halnya dengan pekerjaan pembangunan TMP yang dilakukan oleh imam tentara AD pada waktu sebelumnya di tempat yang lain. Hal ini dijelaskan oleh Anies (1957), 
bahwa tahun 1950 penuh dengan upacara pemindahan jenazah dari parit dan hutanhutan ke makam pahlawan.

Setelah pembangunan TMP di Tanjungpinang selesai, segera ia memenuhi panggilan tugas di tempat lainnya. Tidak lupa semua fasilitas yang diperolehnya sebagai imam tentara AL di Tanjungpinang berupa sebuah mobil jeep dan sebuah rumah dinas di jalan Teluk Keriting 7, Tanjungpinang; dikembalikan semuanya kepada negara. Kemudian, ia pun memboyong keluarganya ke ke Jakarta untuk memenuhi panggilan tugas itu.

Informasi mengenai wafatnya mayor St. Mansyur diperoleh dari informan melalui wawancara, bahwa Ia bersama keluarga berangkat dari pelabuhan Tanjungpinang ke Tanjungpriok, Jakarta dengan menggunakan kapal AL. Setelah tiba di mess AL Jakarta. Ia jatuh sakit kemudian dibawa ke RSAL Jakarta. Keesokan harinya, ia meninggal dunia, Selasa, 30 Januari 1968 (30 Syawal 1387 Hijriah) dalam usia 53 tahun. Setelah penyelenggaraan shalat jenazah kemudian almarhum dimakamkan dengan upacara ketentaraan di TPU Blok-P Kebayoran, Jakarta. Almarhum meninggalkan seorang istri, tiga orang anak yang telah berkeluarga, dan cucu. Berikut foto batu nisan almarhum tertulis St. Mansyur, Mayor IMT NRP.10/PT.DET.M.B.AL (lihat gambar 3).

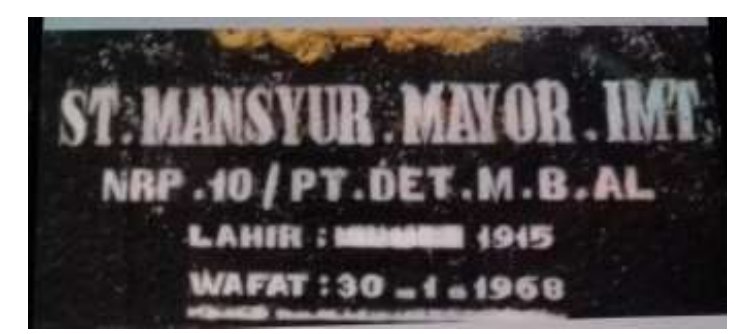

Gambar 3: Foto batu nisan alm. St. Mansyur, Mayor IMT NRP.10/PT.DET.M.B.AL Sumber: Dokumentasi Rasdianto (2021).

Sikap dan tingkah laku semasa hidupnya menunjukkan bahwa ia seorang yang memiliki keahlian dalam menjalankan tugas sebagai guru surau, imam mesjid dan imam tentara. Guru surau, imam mesjid dan imam tentara adalah bentuk-bentuk profesi keahlian dalam ranah pendidikan Islam. Imam tentara disebut sebagai sebuah jabatan profesi yang menuntut keahlian bukan tanpa alasan. Fauzie (2007) menjelaskan, pemerintah melalui kementerian Agama mengadakan salah satu jurusan pendidikan akademis, yaitu jurusan khusus imam tentara di Akademi Dinas Agama (ADIA) Jakarta pada periode tahun 1957-1960 yang kelak menjadi UIN Syarif Hidayatullah Jakarta. Tujuan ADIA untuk mendidik dan mempersiapkan pegawai negeri dalam pendidikan akademis sehingga menjadi guru agama, didirikan tanggal 1 Juni 1957, kemudian tanggal itu ditetapkan sebagai hari jadi UIN tersebut.

Ia melaksanakan profesi pekerjaan ranah pendidikan Islam menurut keahlian dan tanggungjawabnya. Anggaran pelaksanaan kegiatan yang telah diselesaikannya jika terdapat sisa maka semua dikembalikan kepada negara. Ia menjalani hidup sederhana tidak ada upayanya untuk mengumpulkan harta kekayaan dunia, melainkan yang upayanya untuk kebahagiaan dunia dan akhirat. Oleh karena itu, ia tidak meninggalkan warisan berupa harta kekayaan dunia melain yang ditinggalkan berupa nama baiknya dan contoh yang baik bagi keluarga yaitu anak dan keturunannya, masyarakat, bangsa dan negara. Pengabdian sebagai imam tentara dijalani dengan bertakwa kepada Allah 
Wisber Wiryanto: Pengabdian St. Mansyur (1915-1968) Sebagai Guru Surau, Imam Mesjid...

Swt. untuk mendapatkan ridha-Nya, melalui muamalah dengan individu, masyarakat, dan profesi demi terwujudnya manusia yang utuh jasmani dan rohani dijalaninya dengan sikap dan perilaku bekerja dan bertanggungjawab yang dilandasi oleh rasa takut kepada Allah.

\section{Sekilas Imam Tentara dari masa ke masa hingga St. Mansyur}

Sejarah imam tentara tidak lepas kaitannya dari peraturan Menteri Pertahanan yang kemudian ditindaklanjuti baik di lingkungan AD maupun AL. Peraturan itu berupa Penetapan Menteri Pertahanan No. 59/M.P./1949 tentang Tugas dan Susunan Bagian Urusan Agama dari Staf "A" Kementerian Pertahanan, tanggal 3 November 1949. Isi peraturan berupa tugas unit kerja tersebut, yaitu mengadakan pidato keagamaan; memberikan tuntunan tertulis tentang keagamaan; dan mengadakan pelajaran/kursus keagamaan.

Tabel 3: Daftar Imam Tentara TKR-TRI (1945-1948), PRIAD (1949-1957) dan Imam Tentara Angkatan Laut (1954-1970)

\begin{tabular}{|c|c|c|c|}
\hline No. & Nama & Pangkat & Jabatan \\
\hline \multicolumn{4}{|c|}{ 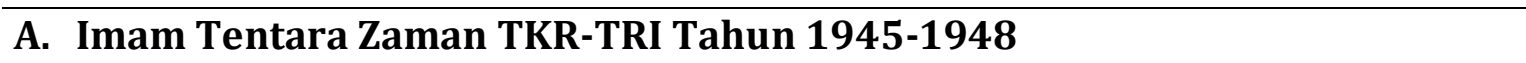 } \\
\hline 1. & $\begin{array}{l}\text { A.R. Sutan } \\
\text { Mansyur }\end{array}$ & $\begin{array}{l}\text { Mayjen } \\
\text { Tituler }\end{array}$ & $\begin{array}{l}\text { Kepala Pemeliharaan Bathin TRI Komandemen } \\
\text { Sumatera di Bukittinggi (1947-1948) }\end{array}$ \\
\hline 2. & H.A. Choliq & - & Imam Penasehat Komando TRI Jawa Timur 1947-1948 \\
\hline 3. & $\begin{array}{l}\text { H. Zainal } \\
\text { Arifin Abbas }\end{array}$ & $\begin{array}{l}\text { Mayor } \\
\text { Tituler }\end{array}$ & $\begin{array}{l}\text { Pimp. Agama TNI Kotaradja (1948) dibantu Lt. Junan } \\
\text { Helmy Nasution, Ltd. M. Djasa SR, Ltd. Iljas Lebeh }\end{array}$ \\
\hline 4. & M. Naswari & - & $\begin{array}{l}\text { Imam Tentara TKR Brigade Tirtayasa Jabar 1946- } \\
1947\end{array}$ \\
\hline 5. & $\begin{array}{l}\text { Shihabuddin } \\
\text { Effendy Idris }\end{array}$ & - & $\begin{array}{l}\text { Imam Tentara TRI Divisi IX Banteng Sumatera Tengah } \\
\text { Padang (1947-1948), dibantu } 11 \text { orang Staf dari TRI }\end{array}$ \\
\hline 6. & Saleh Tarore & Letnan & $\begin{array}{l}\text { Penasehat Keagamaan TRI Yon Pengawal Divisi Gajah } \\
\text { Komandemen Sumatera, dibantu Lt. M. Idris Lubis }\end{array}$ \\
\hline
\end{tabular}

B. Imam Tentara Pemeliharaan Rohani Islam Angkatan Darat (PRIAD) Tahun 1949-1957

1. H. M. Yunus Letkol Kepala Imam Tentara AD (membawahi 174 imam

sd Anies Tituler tentara PRIAD Pusat, Teritorium, KDM,1949-1957)

175.

\section{Imam Tentara Pemeliharaan Rohani Islam Angkatan Laut Tahun 1955- 1970}

1. St. Mansyur Mayor T. Imam Tentara AL (1955-1968)

2. A.M. Fatwa Kapten Imam Tentara AL (1967-1970)

Sumber: Anies (1957), Armyn (2021), ANRI (2021), Suratmin (1999), data diolah.

Berdasarkan data tabel 3, maka diketahui keberadaan imam tentara baik di AD maupun AL, yaitu: (1) AD sudah memiliki imam tentara sejak tahun 1949. Keberadaan imam tentara di Pusat, Daerah/Teritorium tersebut, diindikasikan dari dokumentasi mengenai imam tentara, yaitu: (a) buku berjudul "Sewindhu Imam Tentara Pemeliharaan Rohani Islam AD (3 Nopember 1949-3 Nopember 1957)" yang 
diterbitkan oleh Corps PRIAD (1957); (b) Majalah Imam Tentara AD: Al-Ichlas yang diterbitkan oleh Corps PRIAD, Jakarta (No.1-18 Tahun 1954-1956); dan (c) Buku "Sapta Karya Imam Tentara” yang ditulis oleh Nurdjamil (1957), Bandung: Corps PRIAD Terr. III. Selanjutnya, (2) AL juga memiliki imam tentara, antara lain yang diketahui adalah 1 (satu) orang imam tentara yaitu St. Mansyur, Mayor Tituler yang mulai bertugas di Surabaya pada tahun 1954 hingga akhir hayatnya, wafat di Jakarta, 30 Januari 1968. Selain itu, tidak ditemukan catatan imam tentara yang bertugas sebelumnya. Kecuali, imam tentara yang bertugas sesudahnya, antara lain Kapten A.M. Fatwa sebagai imam tentara AL di Surabaya tahun 1967-1970. Jadi, St. Mansyur, Mayor Tituler adalah seorang Imam Tentara AL yang pertama. Berdasarkan wawancara penulis dengan informan diperoleh informasi, bahwa sebenarnya banyak imam-imam tentara AL di berbagai daerah pada waktu itu. Namun, catatan mengenai mereka tidak ditemukan. Oleh karena itu, perlu dilakukan penelitian lanjutan.

Baru-baru ini, setelah membuat perjanjian terlebih dahulu di akhir tahun 2021, penulis akhirnya berkesempatan mewawancarai salah seorang (satu-satunya) kolega Mayor St. Mansyur yang pernah sama-sama bertugas di Komando Armada Maritim Belawan pada masa dahulu yang kini telah menjadi purnawirawan kolonel ALRI dan telah lanjut usia berumur 87 tahun di Jakarta, pada tanggal 24 Februari 2022. Oleh karenanya, ia merupakan key informant atau sumber penggalian data primer yang darinya diperoleh informasi yang dapat dijadikan sebagai sebuah evidence based penelitian ini.

Ia menjadi saksi mata yang pernah melihat, berjumpa dan mengenali sosok Mayor St. Mansyur sebagai imam tentara yang disebutnya "pak Imam", selama ia mengikuti wajib militer di Komando Daerah Maritim Belawan berpangkat Letnan Satu pada waktu dahulu sekitar tahun 1961-1962. Ia menjelaskan aktivitas Mayor St. Mansyur sebagai imam tentara antara lain mengisi ceramah peringatan Maulid Nabi Muhammad Saw. dan imam shalat. Ia pun mengetahui Mayor St. Mansyur beserta keluarga menempati sebuah rumah dinas perwira AL di Belawan, Medan. Perjumpaan mereka tak lama hanya sekitar 4 (empat) bulan karena ia pindah tugas ke Jakarta. Namun perjumpaan itu, meninggalkan kesan mendalam sebagai sebuah memori yang masih segar dalam ingatannya sampai sekarang. Selanjutnya, berdasarkan informasinya, penulis menelusuri kapan aktivitas Mayor St. Mansyur mengisi ceramah peringatan Maulid Nabi Muhammad Saw. tersebut? Maka diketahui ceramah itu dilakukan di hadapan perwira dan prajurit beserta staf Kodamar Belawan pada hari Senin, 13 Agustus 1962 bertepatan dengan 12 Rabi'ul Awwal 1382 Hijriah. Dengan kata lain, menjelang peringatan hari kemerdekaan RI ke-17 pada hari Jumat, tanggal 17 Agustus 1962.

\section{Pembahasan Aksiologi Terhadap Pengabdian St. Mansyur}

Pembahasan aksiologi dilakukan untuk menjawab pertanyaan mengapa St. Mansyur mengabdi sebagai guru surau, imam mesjid dan imam tentara dalam perspektif pendidikan Islam? Pembahasan ini dimaksudkan untuk mengetahui alasan, dan tujuan pengabdiannya, yaitu: (1) pengabdian St. Mansyur sebagai guru surau; (2) pengabdian St. Mansyur sebagai imam mesjid; dan (3) pengabdian st. Mansyur sebagai imam tentara. Pengabdiannya St. Mansyur sebagai guru Surau, diketahui dari sikap dan tingkahlakunya dalam mengajar mengaji al-Qur'an dan hadits kepada murid-murid di surau yang didirikannya di Guguktinggi. Pekerjaan dilakukan dengan kemampuan profesi mengajar yang diperoleh dalam pendidikan di Thawalib untuk mengamalkan ilmu pengetahuannya. 
Wisber Wiryanto: Pengabdian St. Mansyur (1915-1968) Sebagai Guru Surau, Imam Mesjid...

Indikasi pengabdiannya sebagai guru surau periode 1931-1953, berupa sebuah surau peninggalannya yang dinamakan oleh masyarakat sebagai "surau guru Mansyur" atau "surau buya Mansyur" yang digunakan oleh masyarakat sebagai tempat pengajian sampai sekarang. Ia mengajar pengajian al-Qur'an dan hadits di suraunya. Rachmansyah (2020) menjelaskan, surau buya Mansyur sebagai salah satu sarana prasarana pelaksanaan kegiatan keagamaan yang kondisinya layak pakai. Selain itu, ia melakukan pengkaderan sehingga diantara muridnya ada yang meneruskan pekerjaannya menjadi guru di kampung Guguktinggi dan kampung sekitarnya.

Pengabdian St. Mansyur sebagai imam Mesjid, diketahui dari sikap dan tingkahlakunya sebagai imam mesjid jami' Tabeksarojo karena adanya kebutuhan regenerasi imam mesjid jami' dari yang lama ke yang baru. Imam mesjid yang lama yaitu ayah dari St. Mansyur, meninggal dunia; maka ia dipilih sebagai penggantinya menjadi imam mesjid tersebut. Pengabdian tersebut dilakukan dengan tujuan untuk mengamalkan ilmu pengetahuan yang diperoleh sehingga tamat pendidikan madrasah Thawalib, dengan kemampuan ilmu pengetahuan, dan keahlian yang dimilikinya ia menjadi imam mesjid jami' Tabeksarojo. Indikasi pengabdiannya sebagai imam mesjid jami' Tabeksarojo periode tahun 1932-1953. Ia mengelola urusan penyelenggaraan shalat Jum'at dan kegiatan keagamaan lainnya, jadwal kegiatan shalat Jum'at sebagai imam dan khatib di beberapa mesjid, yaitu mesjid jami' Tabeksarojo; mesjid jami' Rambuti, Guguktinggi; dan mesjid raya Tanjung Pinang pada saat bertugas sebagai imam tentara disana.

Pekerjaan baik sebagai guru surau maupun sebagai imam mesjid dilakukan dengan ketekunan menjalankan pekerjaan sehari-hari (muamalah) sebagai profesi dengan tujuan untuk mendapatkan ridha Allah Swt. Ia membagi pekerjaan untuk memenuhi kebutuhan duniawiahnya dengan menjalankan usaha dagang dan sebagai pengrajin emas. Pekerjaan ini dilaksanakan dengan penuh tanggungjawab. Misalkan perhiasan buatannya ada kerusakan maka ia bertanggungjawab memperbaikinya. Untuk memenuhi kebutuhan jasmani dan rohani atau untuk memenuhi kebutuhan dunia dan akhiratnya, maka ia menjalankan pekerjaan muamalah dengan tujuan untuk mencapai kebaikan hidup dunia dan akhirat dengan bertakwa kepada Allah Swt. untuk mendapatkan ridha-nya.

Pengabdian St. Mansyur sebagai imam Tentara, diketahui dari sikap dan tingkah lakunya dalam tugas penempatan di berbagai daerah yaitu sebagai imam tentara AL di Surabaya, Medan dan Tanjungpinang Pengabdian tersebut dilakukan dengan tujuan untuk mengamalkan ilmu pengetahuan yang diperolehnya sehingga tamat pendidikan Thawalib, dengan kemampuan nya menjalankan profesi ia bertugas menjalankan disiplin bagi para bintara dan perwira dalam menegakkan syariat islam di instransinya. Apabila ia menemukan penyimpangan yang dilakukan oleh tentara AL dalam bidang agama maka ia akan memanggil yang bersangkutan untuk diberikan nasehat. Dengan kata lain, ia melakukan kegiatan pembinaan rohani Islam di lingkungan tentara AL.

Indikasi pengabdiannya antara lain selama ia bekerja sebagai imam tentara AL menerima gaji dari negara. Karena telah digaji maka ia tidak lagi bekerja menjalankan usaha dagang dan usaha pengrajin emas. Jadi, ia hanya menjalankan pekerjaan sebagai imam tentara, karena ia telah memperoleh penghasilan berupa gaji. Walaupun gaji untuk pangkat mayor tituler lebih kecil dari gaji mayor efektif. Sejalan dengan itu, sisa anggaran dalam melaksanakan kegiatan juga dikembalikan kepada negara. Sama halnya, segala fasilitas yang diperolehnya berupa kendaraan mobil dan rumah dinas 
maka ia mengembalikan semuanya kepada negara setelah ia menyelesaikan tugas sebagai imam tentara AL di setiap daerah penempatannya. Selain itu, pemberian dari masyarakat yang diduga berkaitan dengan pekerjaannya semua dikembalikan kepada masyarakat. Ia aktif sebagai imam tentara AL yang pertama pada periode 1955-1968, nama dan kepangkatannya, St. Mansyur, Mayor IMT; dan NRP. 10/PT.DET.M.B.AL, hingga akhir hayatnya, wafat di Jakarta pada hari Selasa, 30 Januari 1968.

Berdasarkan sikap dan tingkahlakunya dalam profesi sebagai imam tentara, maka diketahui bahwa ia melaksanakan pekerjaan dengan keahlian dan tanggungjawab sebagai bentuk amal dengan ilmu dan iman. Ia tidak tergiur untuk menghimpun harta kekayaan. Dengan kata lain, hidup sederhana menjadi pilihannya, karena rasa takut akan tanggungjawab memakan harta yang bukan haknya. Jadi, pengabdian St. Mansyur dalam profesi sebagai imam tentara dilaksanakan dengan bermuamalah untuk kebaikan hidup dunia dan akhirat, dengan bertakwa kepada Allah SWT. untuk mendapat ridha-Nya.

\section{Pembahasan Epistemologi Terhadap Pengabdian St. Mansyur}

Pembahasan dilakukan untuk menjawab pertanyaan bagaimana St. Mansyur mengabdi sebagai guru surau, imam mesjid dan imam tentara dalam perspektif pendidikan Islam? Pembahasan epistemologi dimaksudkan untuk mengetahui proses dan tahapan pengabdiannya, yaitu: (1) pengabdian sebagai guru surau; (2) pengabdian sebagai imam mesjid; dan (3) pengabdian sebagai imam tentara. Berdasarkan hasil penelitian maka diketahui bahwa pengabdian tersebut ditempuh melalui proses dan pentahapan. Baik pada tahapan pertama maupun tahapan kedua, Ia di samping melakukan pengabdian tersebut juga memenuhi kebutuhan duniawiahnya dengan bekerja menjalankan usaha dagang dan sebagai pengrajin emas. Berbeda dengan tahapan ketiga, ia melakukan pengabdian tersebut tidak lagi menjalankan usaha dagang dan sebagai pengrajin emas. Hal itu disebabkan ia telah memperoleh penghasilan berupa gaji.

Berdasarkan hasil pembahasan melalui pendekatan aksiologi dan epistemologi sebagaimana uraian tersebut, maka diketahui bahwa: (1) Pengabdian St. Mansyur sebagai guru surau, imam mesjid dan imam tentara dalam perspektif pendidikan Islam, ia memiliki ketekunan menjalankan pekerjaan sehari-hari dengan ber-muamalah dalam profesi yang mempunyai hubungan relevansi dengan pendidikan Islam. Pekerjaan itu dijalankan dengan tujuan yang berkaitan dengan individu, masyarakat demi terwujudnya manusia yang utuh jasmani dan rohani untuk kebaikan hidup dunia dan akhirat dengan bertakwa pada Allah SWT. untuk mendapat ridha-Nya; dan (2) Pekerjaan St. Mansyur sebagai guru surau, imam mesjid dan imam tentara adalah profesi dalam ranah pendidikan Islam yang ditekuni dan dijalani secara berjenjang melalui proses tahap demi tahap sesuai dengan bertambahnya keahlian dan pengalaman kerja.

Terakhir, (3) St. Mansyur bekerja dengan ikhlas dan tanpa pamrih. Ia tidak tergiur menghimpun harta kekayaan; semua fasilitas yang diterimakan setelah selesai bertugas dikembalikan kepada negara; sisa anggaran pelaksanaan tugas dan kegiatan yang diterimakan semua dikembalikan kepada negara; begitu juga sumbangan dari masyarakat yang diduga berkaitan dengan pekerjaannya semua dikembalikan kepada masyarakat. Oleh karena itu, ia tidak meninggalkan warisan berupa harta kekayaan dunia melainkan nama baik bagi keluarganya dan contoh teladan bagi anak dan cucunya. Sikap hidup tersebut dilakukannya sebagai bentuk pengabdian sebagai guru 
Wisber Wiryanto: Pengabdian St. Mansyur (1915-1968) Sebagai Guru Surau, Imam Mesjid...

surau, imam masjid dan imam tentara yang ditujukan hanya untuk mendapatkan ridha Allah Swt dengan bertakwa kepada-Nya.

\section{Simpulan}

Pertama, St. Mansyur sebagai guru surau, imam mesjid dan imam tentara bermuamalah dengan individu dan masyarakat dengan ketekunan dan keahliannya sebagai bentuk amal dengan ilmu dan iman, sebagai pengabdian untuk mencapai tujuan yang berkaitan dengan individu, masyarakat dan profesi serta terwujudnya manusia yang utuh jasmani dan rohani untuk kebaikan hidup dunia dan akhirat dengan bertakwa pada Allah SWT. untuk mendapat ridha-Nya. Kedua, pekerjaan St. Mansyur sebagai guru surau, imam mesjid dan imam tentara adalah bentuk-bentuk profesi pendidikan Islam yang ditempuh secara berjenjang melalui proses tahap demi tahap sesuai dengan peningkatan keahlian dan pengalaman kerjanya.

Saran pertama, pengabdian St. Mansyur sebagai guru surau, imam mesjid dan imam tentara dalam perspektif pendidikan Islam merupakan sebuah potret profesi masa lalu; diantara bentuk sikap dan tingkah lakunya yang masih relevan dengan masa kini perlu dijadikan referensi dan lesson learned bagi generasi penerus khususnya dalam ranah Ilmu Pendidikan Islam. Kedua, perlu penelitian lanjutan, khususnya tokoh alim ulama di kampung-kampung, termasuk imam tentara tempo dulu lainnya, untuk memperkaya khasanah dan referensi hasil penelitian dan pengembangan konsep ilmu pendidikan Islam.

\section{Referensi}

Abbas, Afifi Fauzi. (2021). Sumatra Thawalib. Retrieved from https://www.scribd.com/doc/17091099/Sumatra-Thawalib-Dr-Afifi, $\quad 12$ Desember 2021.

Abdullah, R., \& Sulaiman, S. (2021). Peranan Organisasi Islam Dalam Membentuk Akhlak Peserta Didik. An-Nuha, 1(2), 143-151. https://doi.org/10.24036/annuha.v1i2.35

Abdullah, Wan Mohd Shaghir. (2021). Syeikh Ahmad Khatib al-Minankabawi - Imam dan Masjid al-Haram Mekah. Retrieved from

https://suraubuya.wordpress.com/2010/07/22/syeikh-ahmad-khatib-alminankabawi-imam-dan-khatib-masjid-al-haram-mekah/ 9 Desember 2021.

Al-Ghazali, Imam. (2013). Ihya Ulumiddin jilid 1 (Terjemahan Ismail Yaqub). Singapura: Pustaka Nasional.

ALRI. (1960). Jalesveva Jayamahe. Jakarta: Djawatan Penerangan Angkatan Laut.

Anies, Muhammad Yunus. (1957). Sewindhu Imam Tentara Pemeliharaan Rohani Islam Angkatan Darat. Jakarta:Pemeliharaan Rohani Islam Angkatan Darat.

ANRI. (2021). Direktori Tokoh Politik. Retrieved from https://kepustakaanpresiden.perpusnas.go.id/election/directory/politician/?box=detail\&id=27\&fr om box=list \&hlm=2\&search ruas=\&search keyword=\&activation status $=, \quad 15$ Desember 2021.

Armyn, Abdullah. (2021). Mengenang Guru Mansjur Zaenal, Mayor Tit. TNI-AL 19121968 (Manuskrip), Jakarta.

Bakry, Oemar. (1984). Tafsir Rahmat.

Darajat, Deden Mauli. (2008). Pemikiran Dakwah dan Pola Kaderisasi K.H. Imam Zarkasyi (Skripsi), Jakarta: Fakultas Dakwah dan Komunikasi, UIN Syarif Hidayatullah. 
Daya, Burhanuddin. (1990). Gerakan Pembaharuan Pemikiran Islam: Kasus Sumatera Thawalib, Yogyakarta: Tiara Wacana Yogya.

Depdiknas. (2018). Kamus Besar Bahasa Indonesia. Jakarta: Penerbit PT Gramedia Pustaka Utama.

Disbintal.com. (2021). Retrieved from https://disbintalal.com/sejarah/, 15 Desember 2021.

Djaelani, M. Anwar \& Nurfatoni, Mohammad. (2021). Yunus Anis Imam Tentara yang Pimpin Muhammadiyah. Retrieved from https://pwmu.co/201260/07/24/yunus-anis-imam-tentara-yang-pimpinmuhammadiyah/, 9 Desember 2021.

Engkizar, E., Munawir, K., Kaputra, S., Arifin, Z., Syafril, S., Anwar, F., \& Mutathahirin, M. (2021). Building of Family-based Islamic Character for Children in Tablighi Jamaat Community. Ta'dib, 24(2), 116-126.

Etek, Azizah, AM, Mursjid \& BR, Arfan. (2007). Koto Gadang Masa Kolonial, Yogyakarta: LKiS.

Fauzie, Ahmad. (2007). Pengaruh Motivasi dan Kompensasi terhadap Kinerja Pegawai Perpustakaan di Lingkungan Universitas Islam Negeri Syarif Hidayatullah Jakarta (Skripsi). Fakultas Ilmu Pengetahuan Budaya, Universitas Indonesia.

Hamka. (1982). Tafsir Al-Azhar Juz XXVII. Jakarta: Penerbit PT Pustaka Panji Mas.

Harahap, Syahrin. (2011). Metodologi Studi Tokoh Pemikian Islam, Jakarta: Prenada Media Group.

Helmy. (2020). Biografi Ali Hasjmy. Retrieved from https://pesantren.laduni.id/post/read/48800/ali-hasjmy-10-ini-karanganpopuler-ali-hasymy, 12 Desember 2021.

Imtihany, Nailul. (2021). Sosok KH Sholeh, Imam Masjid Darussalam. Bojonegoro: Radar Bojonegoro. Retrieved from

https://radarbojonegoro.jawapos.com/berita-daerah/ bojonegoro/01/02/2021/sosok-kh-sholeh-imam-masjid-darussalam, Desember 2021.

Intisari. (1964). Berlebaran dengan Bahrum Rangkuti. Intisari No. 7 Tahun I, 1964. Jakarta.

Ismail, Zamzulis \& Burhanuddin, Sanna. (1977). Siapa Laksamana RE Martadinata, Jakarta: Dinas Sejarah TNI-AL.

Kaputra, S., Engkizar, E., Akyuni, Q., Rahawarin, Y., \& Safarudin, R. (2021). Dampak Pendidikan Orang Tua Terhadap Kebiasaan Religius Anak dalam Keluarga Jama'ah Tabligh. Al-Tadzkiyyah: Jurnal Pendidikan Islam, 12(2), 249-268.

Kasmar, I. F., Amnda, V., Mutathahirin, M., Maulida, A., Sari, W. W., Putra, S., ... \& Engkizar, E. (2019). The Concepts of Mudarris, Mu'allim, Murabbi, Mursyid, Muaddib in Islamic Education. Khalifa: Journal of Islamic Education, 3(2), 107125.

Matanasi, Petrik \& Ahsan, Ivan Aulia. (2019). Bey Arifin: Sejarah Hidup Imam Tentara dan Pemikir untuk Umat. Jakarta: PT Tujuh Cahaya Sentosa. Retrieved from https://tirto.id/bey-arifin-sejarah-hidup-imam-tentara-dan-pemikir-untukumat-dzkL 9 Desember 2021.

Murniyetti, M., Engkizar, E., \& Anwar, F. (2016). Pola pelaksanaan pendidikan karakter terhadap siswa sekolah dasar. Jurnal Pendidikan Karakter, 6(2). 
Wisber Wiryanto: Pengabdian St. Mansyur (1915-1968) Sebagai Guru Surau, Imam Mesjid...

Ningsih, Rona. (2020). Surau Suluk Tertua di Rambah Samo Peninggalan dari Tuan Guru Syekh Ismail. Retrieved from https://www.youtube.com/watch?v=HcLOX8CFoa0, 9 Desember 2021.

Nizar, H. Samsul \& Ramayulis, H.. (2005). Ensiklopedi tokoh pendidikan Islam : mengenal tokoh penddidikan islam di dunia islam dan Indonesia. Jakarta: Quantum Teaching.

Nurdjamil, M.E. (1959). Sapta Karya Imam Tentara. Bandung: Corps PRIAD Terr. III.

Oemarsjahid. (1956). 1 September 1956 Hari Ulang Tahun Ketujuh Imam Tentara, Majalah Imam Tentara AD: Al-Ichlas No. 24 Th. II 1956. Jakarta: Imam Tentara AD.

Rahmansyah, Aswin. (2020). Analisis Kerajinan Perhiasan Masyarakat di Desa Guguk Tinggi Kecamatan IV Koto Kabupaten Agam Sumatera Barat ditinjau menurut Ekonomi Islam (Skripsi). Pekanbaru: UIN Sultan Syarif Kasim Riau.

Rangkuti, Bahrum. (1956). Peraturan Perang Menurut Muhammad SAW, Majalah Imam Tentara AD: Al- Ichlas No. 20 Th. 1956. Jakarta: Imam Tentara AD.

Rangkuti, Bahrum. (1956). Sebab-sebab Adanya Peperangan, Majalah Imam Tentara AD: Al-Ichlas No. 22 Th. II 1956. Jakarta: Imam Tentara AD.

Rangkuti, Bahrum. (1956). Perang dan diplomasi masa Rasulullah SAW. Jakarta: Galundy.

Rangkuti, Bahrum. (1960). Leadership Nabi Muhammad SAW dalam Perang dan Damai. Jakarta: Agus Salim.

Rasyid, Sulaiman. (1992). Fiqh Islam. Bandung: Sinar Baru.

Rustapa, Anita K. (1997). Bahrum Rangkuti dan Pandangan Dunianya, Jakarta: Balai Pustaka.

Sari, W., Anwar, F., Wirdati, W., \& Engkizar, E.. (2021). Metode Diskusi Guru Pendidikan Agama Islam dalam Meningkatkan Kepercayaan Diri Peserta Didik. Jurnal Pendidikan Tambusai, 5(3), 8904-8909.

Setiawan, Taufan \& Baly, Andi. (2021). Anregurutta KH. Abdul Rasyid Pernah Imam Masjid Besar Taqwa Palanro di masanya. Makassar: Kanwil Kemenag Sulsel. Retrieved from https://sulsel.kemenag.go.id/berita/beritawilayah/anregurutta-kh-abdul-rasyid-pernah-imam-masjid-besar-taqwapalanro-dimasanya, 9 Desember 2021.

Tafsir, Ahmad. (2012). Filsafat Ilmu: Mengurai Ontologi, Epistemologo dan Aksiologi Pengetahuan. Bandung: PT Remaja Rosdakarya.

Undang-Undang Republik Indonesia Nomor 12 Tahun 2012 tentang Pendidikan Tinggi;

Yahdi, M. (2019). Pembinaan Mental Tentara dalam Perspektif Al-Qur'an (Disertasi Doktor), Institut PTIQ Jakarta).

Zaim, Muhammad. (2019). Tujuan Pendidikan Perspektif Al-Qur'an dan Hadits (Isu Dan Strategi Pengembangan Pendidikan Islam). Jurnal Muslim Heritage. vol. 4 No 2, November 2019. Ponorogo: STAIN Ponorogo.

Zulkarnain, Fisher. (2017). Pemikiran Politik Islam Zainal Abidin Ahmad, Jurnal Peradaban Islam Tsaqafah Vol.13 No.1 Mei 2017. Ponorogo: Universitas Darussalam Gontor. 